International Journal of Current Advanced Research

ISSN: O: 2319-6475, ISSN: P: 2319 - 6505, Impact Factor: SJIF: 5.995

Available Online at www.journalijcar.org

Volume 6; Issue 3; March 2017; Page No. 2826-2828

DOI: http://dx.doi.org/10.24327/ijcar.2017.2828.0117

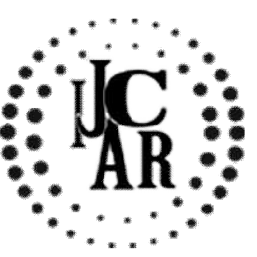

Research Article

\title{
ORAL HEALTH INDEX OF ADOLESCENT SCHOOL CHILDREN IN RURAL AREAS: THIRUVALLUR
}

*Nashwah Hinaz., Dhanraj and Anand

Department of ProsthodonticsSaveetha Dental College

Saveetha University, Chennai-600007

\section{A R T I C L E I N F O}

\section{Article History:}

Received $28^{\text {th }}$ December, 2016

Received in revised form $16^{\text {th }}$ January, 2017

Accepted $6^{\text {th }}$ February, 2017

Published online $28^{\text {th }}$ March, 2017

\section{Key words:}

OHS; rural population; adolescents

\begin{abstract}
A B S T R A C T
Aim : To evaluate the OHS of Adolescent school children in rural areas-Thiruvallur

Objective : Oral Health is often neglected by most people. In an attempt to raise awareness amongst the youngsters or adolescent school children, a survey was conducted in Thiruvallur among students and their OHS was evaluated.

Background : Adequate knowledge regarding oral health is also mandatory as it is directly related to general health. Assessment of the oral health status \& treatment needs, among rural population plays a major role. It is important to note that almost $70 \%$ population in India come under the rural regions.
\end{abstract}

Methods and Methodology: The Oral health status of around 100 adolescents in a school in Thiruvallur was evaluated with the help of an oral hygiene index (simplified) table.Debris Index(simplified) and Calculus Index (simplified) was checked for a minimum of 6 teeth.

Results: It is observed that almost $58 \%$ of the adolescents maintained poor oral health and around $32 \%$ maintained a fair oral health. Only $10 \%$ adolescents maintained good oral health.

Conclusion: This study concluded that the oral health status of adolescents in rural areas of Thiruvallur is poor. Higher the OHI, poorer is the oral hygiene of the individual.

Copyright $\bigcirc 2017$ Nashwah Hinaz., Dhanraj and Anand. This is an open access article distributed under the Creative Commons Attribution License, which permits unrestricted use, distribution, and reproduction in any medium, provided the original work is properly cited.

\section{INTRODUCTION}

Dental hygiene is the science and practice of the recognition, treatment, and prevention of oral diseases. Good oral hygiene is the foundation for a healthy mouth and prevents $80 \%$ of all dental problems ${ }^{1}$. Historically diseases of the oral cavity have been viewed separately from those of the rest of the body. In recent years however efforts have been made to recognize oral health as an integral part of overall health ${ }^{2}$. Oral health index is a method to determine the oral hygiene of an individual. While poor dental status among children has a negative effect on speech development, it may also have a socially stigmatising effect in adolescents affecting social acceptance ${ }^{3}$ . The oral cavity of a healthy individual is a microbially rich environment. The predominant aerobic oral organisms are viridans streptococci. Streptococcus salivarius, one of the first organisms to colonize, can be isolated from the oropharyngeal cavity of infants as soon as 18 hours after birth ${ }^{4}$. Bacterial levels can reach more than $10^{11}$ microorganisms per mg of

\section{*Corresponding author: Nashwah Hinaz}

Department of ProsthodonticsSaveetha Dental College Saveetha University, Chennai-600007 dental plaque. Although the normal inhabitants of the healthy mouth are generally benign, lactic acid produced during metabolism of sugar by organisms such as Streptococcus mutans demineralizes tooth enamel and causes dental caries. In addition, dental plaque may serve as a reservoir for pathogens in patients with poor oral hygiene ${ }^{5}$.

The aim of this study is to describe the oral health status of adolescent schoolchildren in Thiruvallur district of Tamil Nadu. Furthermore, the aim is to ascertain the impact of poor oral health on the quality of life of children in a low-income country, to analyse the association of socio-demographic and behavioural factors with oral health and to investigate possible relationships between oral health and risk factors for chronic disease ${ }^{6}$. These aspects are crucial to oral health promotion and integration of oral disease prevention.

Both the OHI and OHI-S have been used for more than 30 years in studies worldwide]. The Simplified Oral Hygiene Index $(\mathrm{OHI}-\mathrm{S})^{7}$. It was developed to reduce the number of decisions to be made as well as the time required for inspection .Characteristically, it has been reported, 'dental treatment is the greatest unattended health need for adolescents'. Some of the most important reasons may be 
inadequate recall systems, practical difficulties during treatment sessions, socioeconomic status and underestimation of treatment needs or pain, communication problems and bad cooperation $^{8-11}$.

\section{METHODOLOGY AND MATERIALS}

The Oral health status of around 100 adolescents in a school in Thiruvallur was evaluated with the help of an oral hygiene index (simplified) table. Debris Index (simplified) and Calculus Index (simplified) was checked for a minimum of 6 teeth. From the Debris index and calculus index the oral hygiene index score of the adolescent was calculated.Based on which the oral hygiene status of the individual was found. Criteria for calculating debris index and calculus index:

Each segment is examined for debris or calculus. From each segment, one representative tooth is used for calculating the individual index. The representative tooth used for the calculation must have the greatest area covered by either debris or calculus. The debris index ranges from 0 (no debris or stain) to 3 (soft debris covering more than $2 / 3$ of the exposed tooth surface). The calculus index has similar scoring, ranging from 0 (no calculus present) to 3 (calculus covering more than 2/3 of the exposed tooth surface). The debris and calculus scores are then each totalled and divided by the number of surfaces scored. The average debris and calculus scores are combined to obtain the OHI, which ranges from 0 to 6 .

\section{RESULTS AND DISCUSSIONS}

\section{GENDER}

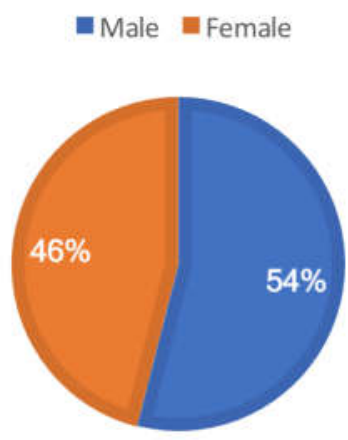

Figure 1

\section{ORAL HYGIENE STATUS}

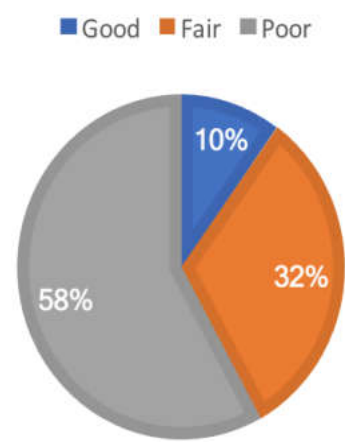

Figure 2

\section{AGE GROUP}

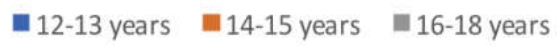

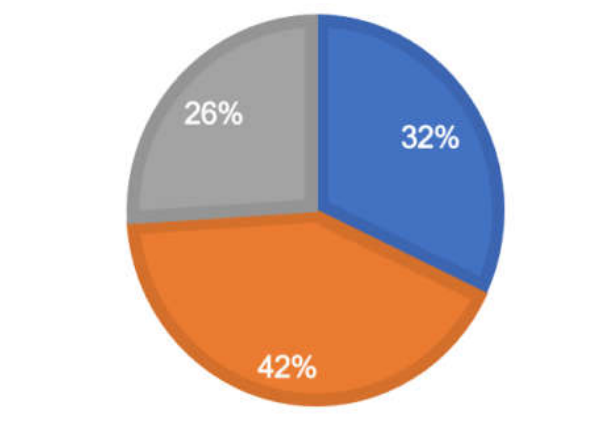

Figure 3

The OHI-simplified was checked for a sample size of 100 adolescents in the rural areas of Thiruvallur and based on it the data was evaluated.Oral Health is often neglected by most people. In an attempt to raise awareness amongst the youngsters or adolescent school children, a survey was conducted in Thiruvallur among students and their OHS was evaluated.46\% of the population comprises of males and $54 \%$ population comprises of women(fig 1). $32 \%$ adolescents come under the age 12-13years and $42 \%$ come under $14-15$ years.Adolescents of age group 16-18 years comprise $26 \%$ (fig2).It is observed that almost $58 \%$ of the adolescents maintain poor oral health and around $32 \%$ maintain a fair oral health. Only $10 \%$ adolescents maintain good oral health. (fig 3).

\section{DISCUSSIONS}

Hygiene is a science concerned with the investigations of environmental factors that affect human health. It studies how the human body responds to them.It is observed that higher percentage of corporation school children had gingival and periodontal problems than private school children. It was seen that oral hygiene score showed increase with age and boys were affected more ${ }^{12}$. Since presence of plaque and gingivitis in these ages determine the periodontal health at later ages, such research has the potential to indicate future health of this population ${ }^{13}$

\section{CONCLUSION}

This study concluded that the oral health status of adolescents in rural areas of Thiruvallur is poor. Higher the OHI, poorer is the oral hygiene of the individual. Hence it is at most important to maintain good oral hygiene. The adolescents of the rural areas have to stress on the importance of good oral health and should be more aware of the negative effects of bad oral health. The oral health of the disabled may be neglected because of the disability condition, a demanding disease or limited access to oral health care. However, with appropriate planning, clear communication and carefully drawn limits to the service provided, the dramatic dental neglect experienced by the majority of these individuals can be successfully alleviated ${ }^{14}$. 


\section{References}

1. Bakdash B. Current patterns of oral hygiene product use and practices. Periodontol 2000. 1995;8:11-4.

2. Petersen PE: The World Oral Health Report 2003: continuous improvement of oral health in the 21 st century-the approach of the WHO Global Oral Health Programme.Community Dent Oral Epidemiol. 2003, 31 (Suppl 1): 3-23. 10.1046/j..2003.com122.x.

3. Jiang H, Petersen PE, Peng B, Tai B, Bian Z: Selfassessed dental health, oral health practices, and general health behaviors in Chinese urban adolescents. Acta Odontol Scand. 2005, 63: 343-352. 10.1080/00016350500216982.

4. Oral Health Measurement in Nursing Research: State of the Science. Cindy L. Munro, RN, ANP, PhD, FAAN, Mary Jo Grap, RN, ACNP, PhD, FAAN, [...], and Anne Boyle, RN, CNE, PhD.

5. Greene JC. The Oral Hygiene Index-Development and uses. Journal of Periodontology. 1967;38 (Suppl):37. [PubMed]

6. Oral health and the impact of socio-behavioural factors in a cross sectional survey of 12-year old school children in Laos. Nanna Jürgensen Email author and Poul Erik Petersen BMC Oral Health 20099:29.

7. Greene JC, Vermillion JR. The Simplified Oral Hygiene Index. Journal of the American Dental

8. Boj JR, Davila JM. Differences between normal and developmentally disabled children in a first dental visit. $J$ Dent Child 1995; 62:52-6.
9. Brandes DA, Wilson S, Preisch JW, Casamassimo PS. A comparison of opinions from parents of disabled and non-disabled children on behavioral management techniques used in dentistry. Spec Care Dent 1995;15:119-23. 78910

10. Dicks JL. Outpatient dental services for individuals with mental illness: A program description. Spec Care Dent 1995; 15:239-42.

11. Glassman R, Miller CE, Lechowick A. A dental school's role in developing a rural, community based, dental care delivery system for individuals with developmental disabilities. Spec Car Dent 1996;16:188-93

12. Krawczyk D, Pels E, Prucia G, Kosek K, Hoehne D. Students' knowledge of oral hygiene vs its use in practice. Adv Med Sci 2006;51 Suppl 1:122-5.

13. Oral Hygiene Status, Knowledge, Perceptions and Practices among School Settings in rural South India,Vyshalee L Kuppuswamy, Shruti Murthy, Shruti Sharma, Krishna M Surapaneni, Ashoo Grover, Ashish JoshiSaveetha Medical College and Hospital, Saveetha University, Chennai, Tamil Nadu, India. Foundation of Healthcare Technologies Society, New Delhi, India. Indian Council of Medical Research, New Delhi, India. Center for Global Health and Development, College of Public Health, University of Nebraska Medical Center, Omaha, USA.

14. Haavio ML. Oral health care of the mentally retarded and other persons with disabilities in the Nordic countries: Present situation. Spec Care Dent 1995; 15:65-9.

\section{Please cite this article in press as:}

Nashwah Hinaz., Dhanraj and Anand (2017), Oral Health Index Of Adolescent School Children In Rural Areas: Thiruvallur, International Journal of Current Advanced Research, 6(3), pp. 2826-2828. http://dx.doi.org/10.24327/ijcar.2017.2828.0117 